\title{
Calpain: a molecule to induce AIF-mediated necroptosis in RGC-5 following elevated hydrostatic pressure
}

\author{
Lei Shang ${ }^{1}$, Ju-Fang Huang ${ }^{1}$, Wei Ding ${ }^{1}$, Shuang Chen ${ }^{1}$, Li-Xiang Xue ${ }^{2}$, Ruo-Fei Ma ${ }^{3}$ and Kun Xiong ${ }^{1 *}$
}

\begin{abstract}
Background: RIP3 (Receptor-interacting protein 3) pathway was mainly described as the molecular mechanism of necroptosis (programmed necrosis). But recently, non-RIP3 pathways were found to mediate necroptosis. We deliberate to investigate the effect of calpain, a molecule to induce necroptosis as reported (Cell Death Differ 19:245-256, 2012), in RGC-5 following elevated hydrostatic pressure.

Results: First, we identified the existence of necroptosis of RGC-5 after insult by using necrostatin-1 (Nec-1, necroptosis inhibitor) detected by flow cytometry. Immunofluorescence staining and western blot were used to detect the expression of calpain. Western blot analysis was carried out to describe the truncated AIF (tAIF) expression with or without pretreatment of ALLN (calpain activity inhibitor). Following elevated hydrostatic pressure, necroptotic cells pretreated with or without ALLN was stained by Annexin V/PI, The activity of calpain was also examined to confirm the inhibition effect of ALLN. The results showed that after cell injury there was an upregulation of calpain expression. Upon adding ALLN, the calpain activity was inhibited, and tAIF production was reduced upon injury along with the decreased number of necroptosis cells.
\end{abstract}

Conclusion: Our study found that calpain may induce necroptosis via tAlF-modulation in RGC-5 following elevated hydrostatic pressure.

Keywords: Retinal ganglion cells-5, Calpain, Elevated hydrostatic pressure, tAlF, Necroptosis

\section{Background}

Calpains are calcium-activated neutral protease, which belongs to the family of cytosolic cysteine proteinases. They form heterodimers which are composed of a large $80 \mathrm{kDa}$ catalytic subunit and a common $30 \mathrm{kDa}$ regulatory subunit [1]. The calpains are widely distributed in most of the mammal tissues. The calpains are also implicated in physiological and pathophysiological processes, such as cytoskeletal reorganization, signal transduction pathways, cell cycle regulation and certain apoptosis pathways. The dysfunction of calpains is related to certain diseases like cataract, Parkinson's disease and Alzheimer's disease [2-5].

\footnotetext{
* Correspondence: xiongkun2001@163.com

'Department of Anatomy and Neurobiology, Central South University School of Basic Medical Sciences, 172 Tongzi Po Road, 410013 Changsha, Hunan, China

Full list of author information is available at the end of the article
}

During cerebral hypoxic-ischemia, there's an overload of intracellular calcium which activates calpains, as a result neuronal apoptosis is triggered via caspase-3 activated pathway [6]. Recent studies show that calpains, caspase-3, caspase- 8 and caspase- 9 are all up-regulated in experimental retinal detachment, which suggests calpains are involved in caspase-dependent photoreceptor death [7]. Pharmacological inhibition of phosphodiesterase 6 (PDE6) induces retinal degeneration in rod and cone-enriched retinal explants with activation of caspase-3, calpain and poly (ADP-ribose) accumulation, which suggests a potential connection between calpain activation and apoptosis [8]. However, besides its role in apoptosis, a new feature of calpains has been found recently. Cellular necrosis, which is mediated by recombinant clostridium perfringens b-toxin (rCPB) occurs upon the activation of host cell calpains [9]. Another study reported that calpains may be involved in necroptosis as well [10]. Calcium-dependent calpain is activated by increasing calcium concentration in cytoplasm in 
$\mathrm{N}$-methyl-N'-nitro-N'-nitrosoguanidine (MNNG)-treated cells. The activated calpains cleaves BID (BH3 interacting domain death agonist) to trucked BID sequent; tBID redistributes from the cytosol to mitochondria where it regulates BAX (Bcl-2-associated X protein) activation. Once activated, BAX provoked mitochondrial tAIF release and resulted in necroptosis $[10,11]$.

High intra-ocular pressure (HIOP) is identified as one of the characteristics of glaucoma and it is the main factor that causes visual functional damage [12]. Related studies have been confirmed that elevation, volatility and continuous rise of intraocular pressure (IOP) could cause the death of retinal ganglion cells (RGCs), retinal pigment epithelium cells, etc. and eventually lead to vision loss $[13,14]$. Rapid elevation of IOP is a critical susceptible factor that causes acute glaucoma. The study indicated that RGCs necroptosis could also exist at the early stage of aHIOP (acute high intra-ocular pressure) [15]. Our further investigation suggested that up-regulation of receptorinteracting protein 3 (RIP3) might be involved in cellular mechanism of RGCs necroptosis [16]. As reported previously, RIPs is not the only cellular pathway which modulates early neuronal necroptosis, other cellular pathways may also participate in this process [17-19]. As mentioned earlier, the potential role of calpain involved in necroptosis in RGC after aHIOP is still unknown and further studies need to be done to evaluate it. Moreover, the various types of complex pathophysiological mechanisms in aHIOPinduced retinal injury, including retinal hypoxic-ischemia, accumulation of excitatory amino acid and inflammatory molecules, etc. needs to be considered [20,21]. But little is currently known about whether there is necroptosis in RGC under elevated hydrostatic condition, which is an initial factor in aHIOP-induced retinal injury in vivo, hence, we investigated the existence of necroptosis in elevated hydrostatic condition states by PI-staining and flow cytometry, and then evaluated the effect of calpain in necroptosis of RGC under elevated hydrostatic condition. We expect that the results will lead to a better understanding of the cellular mechanism of early RGC necroptosis and looking for rational interventional targeted therapy in the future.

\section{Methods}

\section{Cell culture}

The mouse retinal ganglion cell line (RGC-5) was contributed by Department of Ophthalmology, Second Hospital of Ji Lin University in China [22]. RGC-5 cells grew in Dulbecco's Modified Eagle Medium (DMEM) (HyClone Laboratories, Inc. UT) and supplemented with $10 \%$ fetal bovine serum (FBS, HyClone Laboratories, Inc. UT), 100 $\mathrm{U} / \mathrm{ml}$ of penicillin and $100 \mu \mathrm{g} / \mathrm{ml}$ of streptomycin (HyClone Laboratories, Inc. UT). The RGC-5 cells used in the experiment were within 2-3 passages post-thawed to minimize the variability in the assays based on our observations. The density of RGC-5 cells was around $80 \%$ in $6 \mathrm{ml}$ culture media in $50 \mathrm{ml}$ flask before EHP (elevated hydrostatic pressure).

\section{PCR analysis}

The cells cultured in the flasks were harvested and RNA was isolated using TRIzol (Invitrogen, Carlsbad, CA). cDNA was synthesized using Thermoscript (Invitrogen, Carlsbad, CA) from $1 \mu \mathrm{g}$ of total RNA. Each primer pair $(\beta$-actin: forward primer

5'-CAACTTGATGTATGAAGGCTTTGGT-3'

reverse primer $5^{\prime}$-ACTTTTATTGGTCTCAAGTCAG TGTACAG-3'.

NGF: forward primer 5'-AGAACCGTACACAGATAG CAA-3'

reverse primer 5' -TTAATGTTCACCTCGCCCAG-3' . BDNF: forward primer 5'-AAAACCATAAGGACGC GGACTT-3'

reverse primer 5' -AAAGAGCAGAGGAGGCTCCAA-3'.

GFAP: forward primer 5'-ACGCAATTCCATTTTA CCTG-3'

reverse primer 5'-AGGCCATAACTCATGCAAC-3') was designed to cross at least one intron and was specific to the gene of interest. Negative control was used diluted water for instead. Oligonucleotide primers that recognized the housekeeping gene $\beta$-actin were used as normalized control. PCR program consisted of $94^{\circ} \mathrm{C}$ for $3 \mathrm{~min}, 36 \mathrm{cy}$ cles of $94^{\circ} \mathrm{C}$ for $45 \mathrm{~s}, 55^{\circ} \mathrm{C}$ for $50 \mathrm{~s}$, and $72^{\circ} \mathrm{C}$ for $2 \mathrm{~min}$, with a final extension at $72^{\circ} \mathrm{C}$ for $10 \mathrm{~min}$.

\section{Immunofluorescence staining}

The coverslips with fixed cells were washed in 0.01 M PBS for $3 \mathrm{~min}$, incubated in 5\% BSA and then reacted with anti-rabbit calpain antibody (Abcam, ab39170, USA, 1:500) or anti-rabbit Brn3a (Boster, BA1773, China, 1:200) and anti-mouse THY1.1 (Abcam, ab8872, USA, 1:500) overnight. Then coverslips were reacted with $\mathrm{Cy} 2$ or $\mathrm{Cy3}-$ conjugated donkey anti-rabbit or anti-mouse secondary antibodies at 1:200 (Invitrogen, USA). Counterstaining with DAPI, then covered with an anti-fading mounting medium before microscopic examination. Control RGC-5 incubated simultaneously in a conventional incubator at $37^{\circ} \mathrm{C}$.

\section{Cell injury and ALLN or Nec-1 usage}

A pressurized incubator was designed to expose the cells to an elevated hydrostatic pressure as described in Ju's study [23]. After $2 \mathrm{hr}$ exposure in this pressure system, the pressure present in three different values: $100 \mathrm{mmHg}$, $60 \mathrm{mmHg}$ and $30 \mathrm{mmHg}$, cells were then moved to conventional culture incubator to recover at each recovery time point (6 hr, $12 \mathrm{hr}$ and $24 \mathrm{hr}$ ). ALLN (Merck, Germany) and Nec-1 (Sigma-Aldrich, USA) were dissolved 
in Dimethyl sulfoxide (DMSO) for storage in $10 \mathrm{mmol} / \mathrm{L}$ and $1 \mathrm{mg} / \mathrm{mL}$, which were pretreated in $10 \mu \mathrm{mol} / \mathrm{L}$ for $24 \mathrm{hr}$ before cell injury.

\section{PI staining}

At each recovery time point ( $6 \mathrm{hr}, 12 \mathrm{hr}$ and $24 \mathrm{hr}$ ), the coverslips were washed in $0.01 \mathrm{M} \mathrm{PBS}$ for $3 \mathrm{~min}$, and incubated in $10 \mu \mathrm{g} / \mathrm{ml}$ PI-dye solution at $37^{\circ} \mathrm{C}$. After that, cells were fixed in 4\% PF (Paraformaldehyde) and washed in PBS counterstaining with DAPI, and then covered with anti-fading mounting medium before microscopic examination. Control RGC-5 was incubated simultaneously in a conventional incubator at $37^{\circ} \mathrm{C}$. Quantitative analyses were conducted using approximately 20 merged images (magnification $=40 \times$ ) to estimate the frequency of cell necrosis.

\section{Western blot}

At each survival time point, cells were digested by sonication on ice in a digestion buffer [ $150 \mathrm{mM} \mathrm{NaCl}, 25 \mathrm{mM}$ Tris-HCl (pH 7.4), 2 mM EDTA, 1.0\% Triton X-100, 1.0\% sodium deoxycholate, $0.1 \%$ SDS] containing a cocktail of protease inhibitors (Sigma, USA). Cell lysates were centrifuged at $10,000 \times g$ for $20 \mathrm{~min}$ at $4^{\circ} \mathrm{C}$. The supernatants were collected, and protein concentration was determined by Bicinnchoninic acid (BCA) assay (Pierce, USA). A total of $100 \mu \mathrm{g}$ of protein in $62.5 \mathrm{mM}$ Tris loading buffer ( $\mathrm{pH}$ 6.8, containing 25\% glycerol, 2\% SDS, 0.01\% bromophenol blue and 5\% $\beta$-mercaptoethanol, Bio-Rad, USA) was boiled for $10 \mathrm{~min}$, and loaded into each lane of 4-20\% linear gradient Tris- $\mathrm{HCl}$ ready gel (Bio-Rad, USA). The polypeptides were electrotransferred to Trans-Blot pure nitrocellulose membrane (Bio-Rad, USA). Non-specific binding was blocked with PBS containing 5\% nonfat milk (Bio-Rad, USA) and 3\% bovine serum albumin (Sigma, USA). Membranes were incubated with tAIF (Santa Cruz biotechnology Inc, SC-113116, USA, 1: 200), $\beta$-tubulin (Abcam, ab6046, USA, 1:1000), calpain (Abcam, ab39170, USA, 1:500) or actin (Abcam, ab3280, USA, 1:500) antibodies overnight, and then in HRP-conjugated secondary antibodies (1:20000, Bio-Rad, USA) for $1 \mathrm{hr}$. Immunoblotting products were visualized with an ECL Plus ${ }^{\mathrm{Tm}}$ Western Blotting Detection kit according to manufacturer's instruction (GE Healthcare Life Sci., USA), and images were captured in a Molecular Dynamics Phosphor imager (Nucleo Tech Inc., USA). Western blot bands were measured with Image J (National Institutes of Health, USA) to analyze the integrated density value (IDV). The average IDV values of tAIF or calpain with $\beta$-tubulin and actin were compared, and the average relative value was obtained.

\section{Flow cytometry}

The cells attached to the flasks were trypsinized followed by a gentle wash. Resuspending the cells in $200 \mu \mathrm{l}$ of $1 \times$ binding buffer, and then added $5 \mu \mathrm{l}$ of $20 \mu \mathrm{g} / \mathrm{ml}$ Annexin
$\mathrm{V}$ and $10 \mu \mathrm{l}$ of $50 \mathrm{mg} / \mathrm{ml} \mathrm{PI}$, incubated at RT for $15 \mathrm{~min}$ in the dark. After the cells were washed and analyzed by FACS Calibur (Becton, Dickinson Company, USA). The percentages of cells in each quadrant were analyzed using ModFit software (Verity Software House Topsham, USA). Statistical results of flow cytometry were conducted by calculating the PI+ cells numbers. All the results were repeated for three times.

\section{Calpain activity assay}

Calpain activity was determined by cleavage of the substrate Ac-LLY-AFC (Abcam, USA). The attached cell were digested, and then centrifuged for $1 \mathrm{~min}$ in a microcentrifuge $(10,000 \times g)$ then the supernatant was transferred to a fresh tube, a part of the supernatant were used to measure the protein concentration. The fluorescence was measured after $60 \mathrm{~min}$ incubation at $37^{\circ} \mathrm{C}$ along with the substrate in the reaction buffer. Fluorescence was recorded in a Fluoroskan Ascent Fluorimeter (Labsystems, Eragny-Parc, France), and the final results were expressed as Relative Fluorescent Unit (RFU) per milligram protein of each sample.

\section{Data analysis}

Figure panels were assembled by using Photoshop CC. The data were analyzed by using SPSS 19.0 (SPSS, USA). One-way analysis of variance (one-way ANOVA) was performed to test differences in average value between groups. All results were presented as mean $\pm \mathrm{SD}$. A value of $p<0.05$ was considered statistically significant.

\section{Results}

RGC-5 has the same features with retinal ganglion cells First we verified that the RGC-5 cells in our culture conditions expressed BDNF and NGF, but not GFAP (Figure 1A). As shown in Figure 1B, the cells expressed RGC marker Brn3a and Thy1.1. The transcription factor Brn3a was expressed and appears to localize at the nuclei of RGC-5 cells. On the other hand, the expression of Thy 1.1 was detected in the cytoplasm of RGC-5 cells. Negative control immunostaining (second antibody only) showed no positive signal (data not shown), confirming the specificity of the antibodies. Therefore, expression of RGC marker genes and protein indicated that the cells cultured were RGCs.

\section{Necroptosis happened at early stage of EHP}

Propidium iodide (PI) is one of the dyes that emit red fluorescent under the excitation of $535 \mathrm{~nm}$ with the combination of DNA double strain through necrosis cell's membrane, but it does not penetrate into live cells. Thus, PI dye can be used to distinguish the necrosis cell from normal ones [24-27]. DAPI is one of the dyes that emit blue fluorescent under the excitation of $340 \mathrm{~nm}$ with the combination of DNA double strain through $4 \%$ PF fixation. It can identify PI-staining to be a realistic cell 


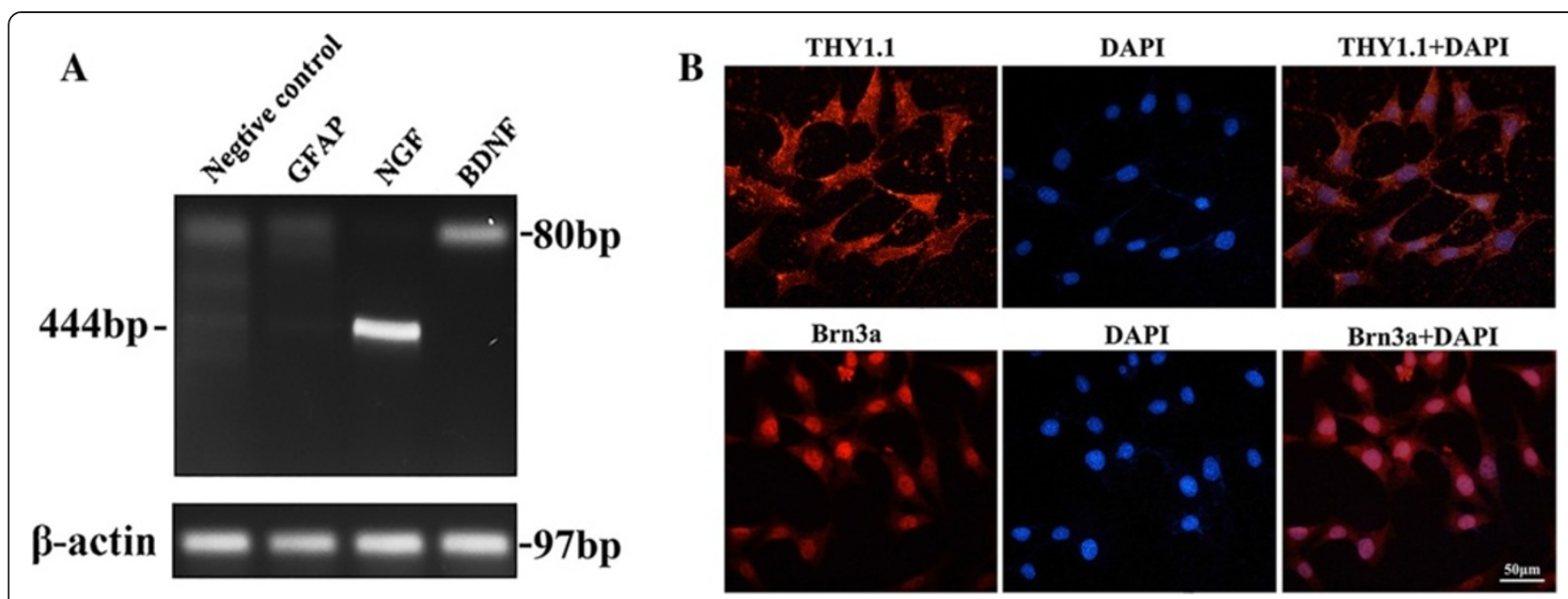

Figure 1 Identification of RGC-5 cell line. Panel A: RT-PCR show retinal ganglion cell marker gene expressed in our cultured cell, Panel B: Two other types of protein marker also detected with immunostaining, scale bar $=50 \mu \mathrm{m}$.

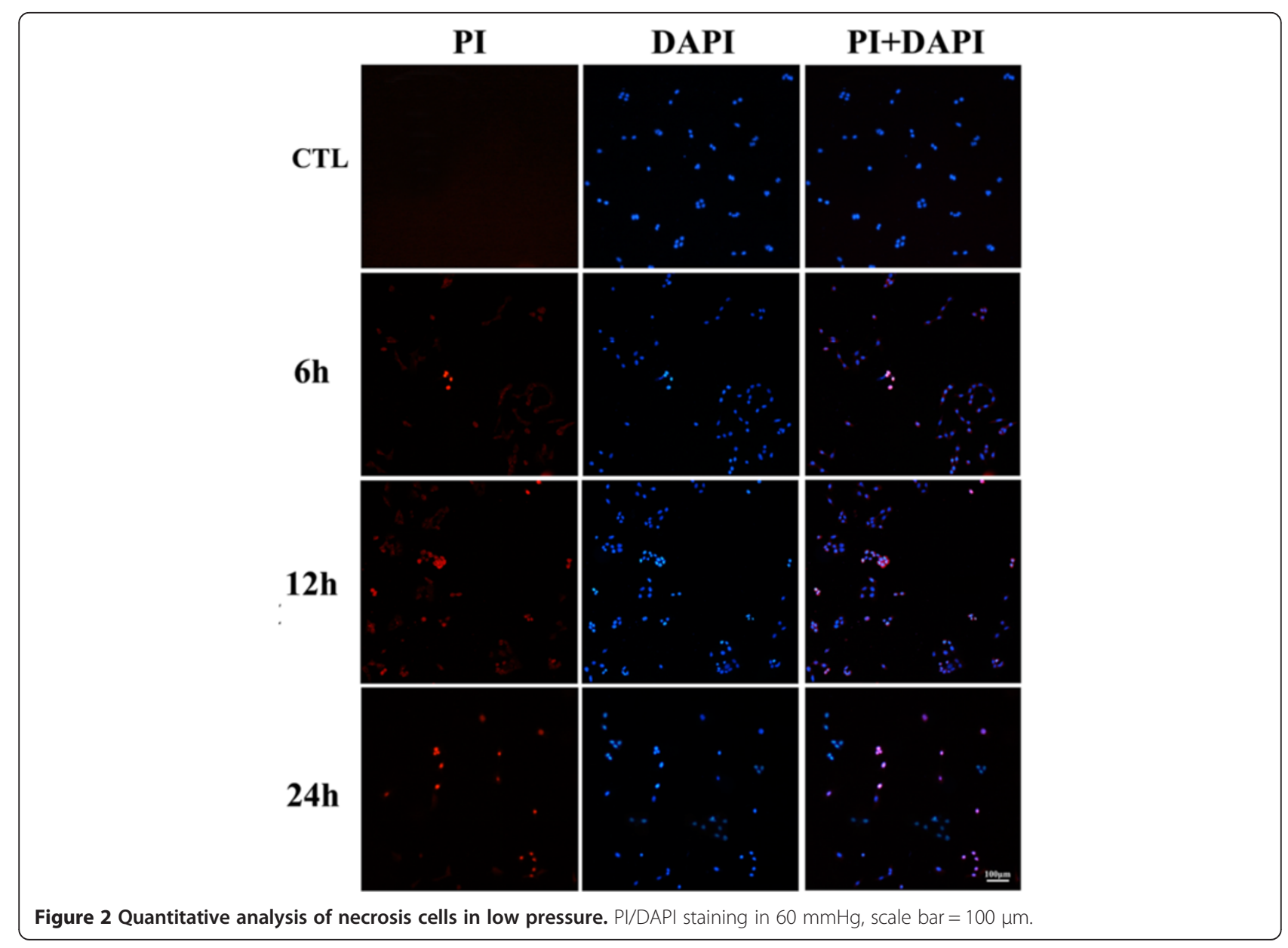


but not false-positive dying [28]. The double labeling of PI and DAPI showed that there was no significant PI staining in $30 \mathrm{mmHg}$ insults (data not shown). With the counterstaining of DAPI, a few PI-positive cells were observed in the condition of $60 \mathrm{mmHg}$ (Figure 2). In our observation time point, the number of PI-positive cells gradually increased to $13.45 \%$ in $12 \mathrm{hr}$ and decreased to $4.32 \%$ afterward in $24 \mathrm{hr}$ (Figure 3B). In the condition of high pressure in $100 \mathrm{mmHg}$, necrosis also occurs at $6 \mathrm{hr}$ (Figure 3A). The number of PI-positive cells reached $15.35 \%$ at $12 \mathrm{hr}$, and gradually decreased at $24 \mathrm{hr}$ (Figure 3B). These results indicated that within our observation time point, there was a small number of necrosis in RGC-5 cell line under $60 \mathrm{mmHg}$ and the degree of cell necrosis increased following the pressure elevation (Figure 3B). During the same time point, we observed that as the pressure level elevated, the number of necrosis cells increased too. This result indicates that RGC-5 necrosis is affected in a pressure-dependent manner. Correspondingly, it is suggested that under $100 \mathrm{mmHg}$ there is more necrosis cells in RGC-5. In order to be consistent with the conditions in vivo [29], we believed that $100 \mathrm{mmHg}$ insult condition was suitable for the next step of our experiment for necroptosis detection.

It's difficult to precisely identify between necroptosis, apoptosis or necrosis in various methods until recently [30]. Nec-1 is the specific inhibitor of necroptosis, as reported in other studies the cell number of necrosis decreased when using it $[31,32]$. In order to analyze necroptosis, we detected the PI-positive cells to analyze cellular necroptosis by flow cytometry with PI/Annexin $\mathrm{V}$ double staining using Nec-1. In our model of cell injury in $24 \mathrm{hr}$ in $100 \mathrm{mmHg}$, we found that the ratio of necrosis cells (PI+) was about $13 \%$ (Figure 4B), but the percentage decreased to nearly $5 \%$ (Figure 4C) within the use of Nec-1 which have significant difference in statistical analysis (Figure 4D). These results indicate that with the exposure of Nec-1, necrosis is inhibited, thus necroptosis occurred after EHP.

\section{Calpain is up-regulated following elevated hydrostatic pressure}

Immunofluorescence staining results showed that calpain is mainly present in cytoplasm in normal control group in RGC-5 (Figure 5A); meanwhile, no difference in distribution was observed between injury group and normal controls. Generally, in contrast with the normal controls, significantly more distinct and heavier calpain immunoreactive was found with strong cellular labeling of calpain in $6 \mathrm{hr}$ and $12 \mathrm{hr}$ groups in high pressure models, but weaker labelling in $24 \mathrm{hr}$ group. The western blot results showed that calpain exhibited mainly as a single $75 \mathrm{kDa}$ band in all groups (Figure 5B). The bands in high pressure groups were apparently thicker and larger than those of normal control groups. The bands in $24 \mathrm{hr}$ group were thinner and smaller than those in injury groups and tended to be normal. Statistical analysis of IDV indicated that high pressure up-regulated the expression of calpain in the

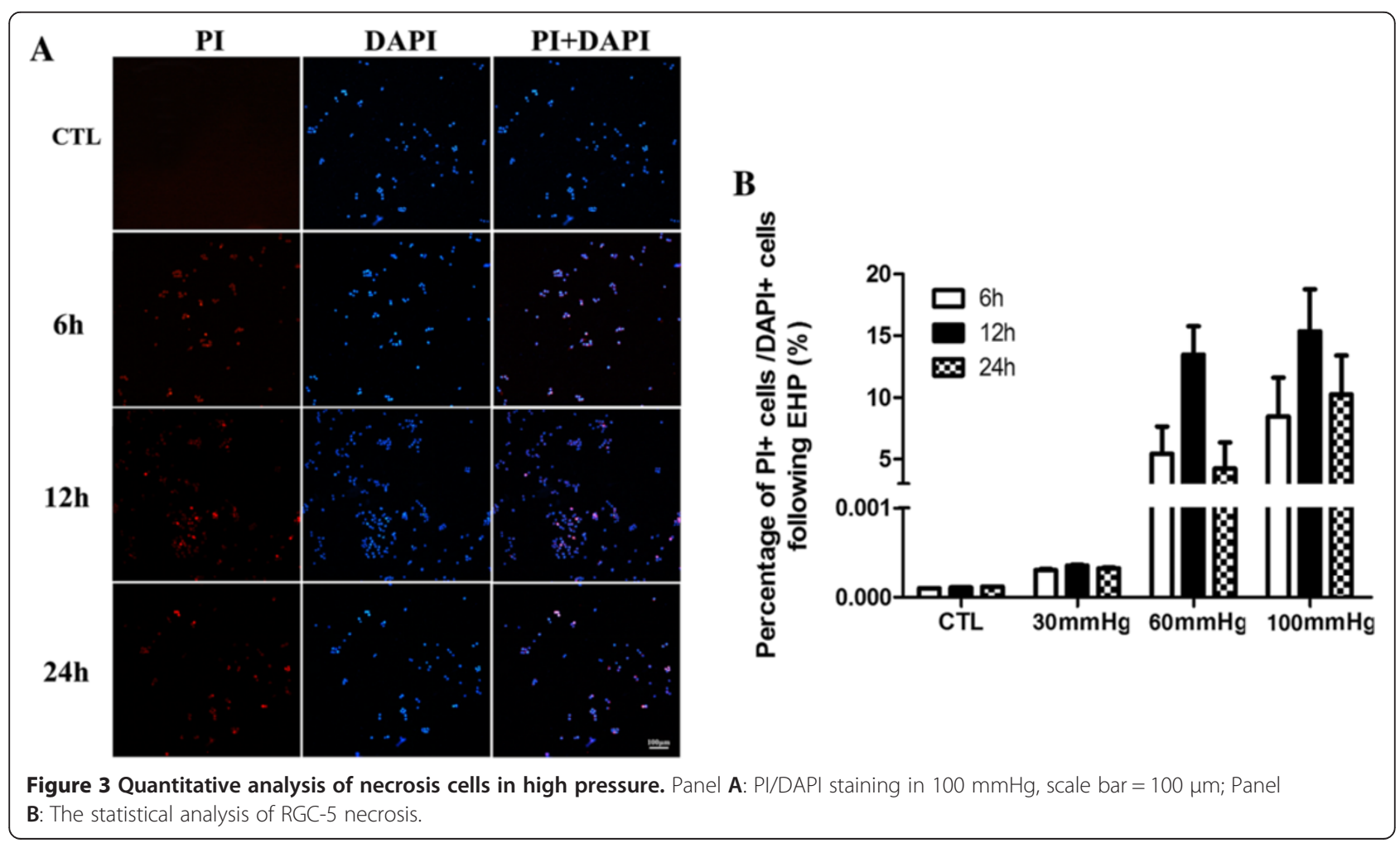



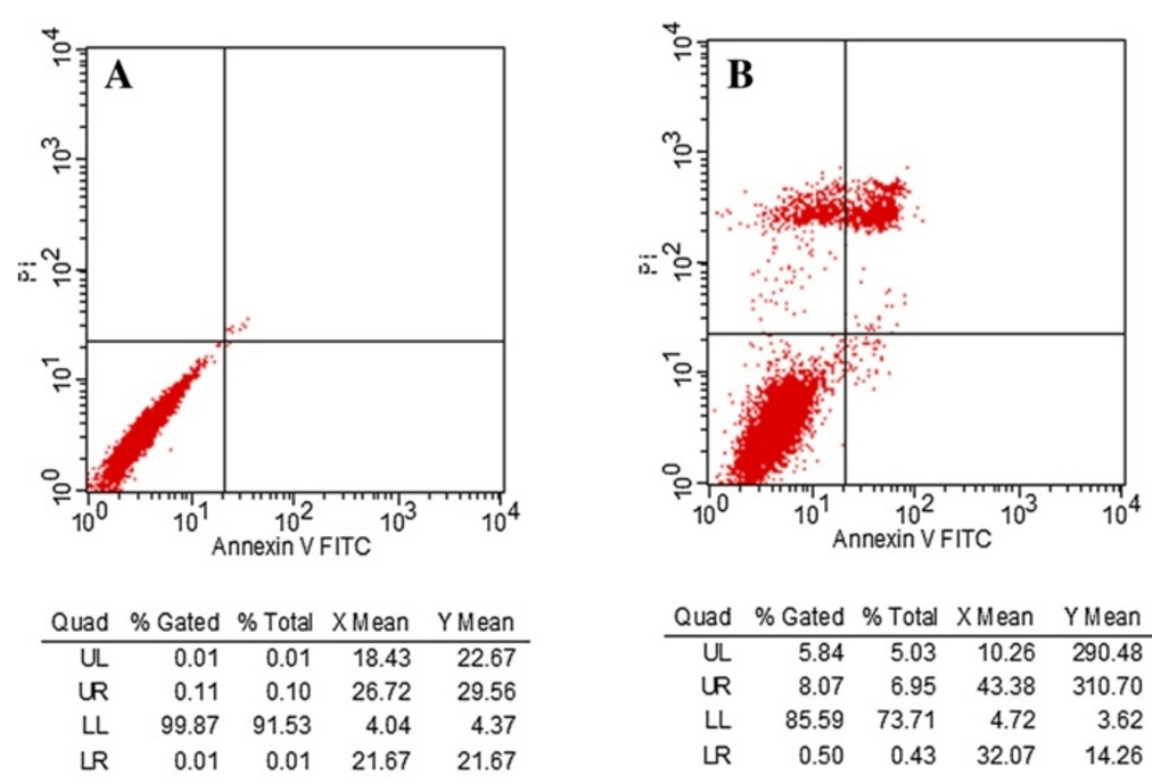

\begin{tabular}{crrrr} 
Quad & \% Gated & \% Total & X Mean & Y Mean \\
\hline UL & 5.84 & 5.03 & 10.26 & 290.48 \\
UR & 8.07 & 6.95 & 43.38 & 310.70 \\
LL & 85.59 & 73.71 & 4.72 & 3.62 \\
LR & 0.50 & 0.43 & 32.07 & 14.26
\end{tabular}
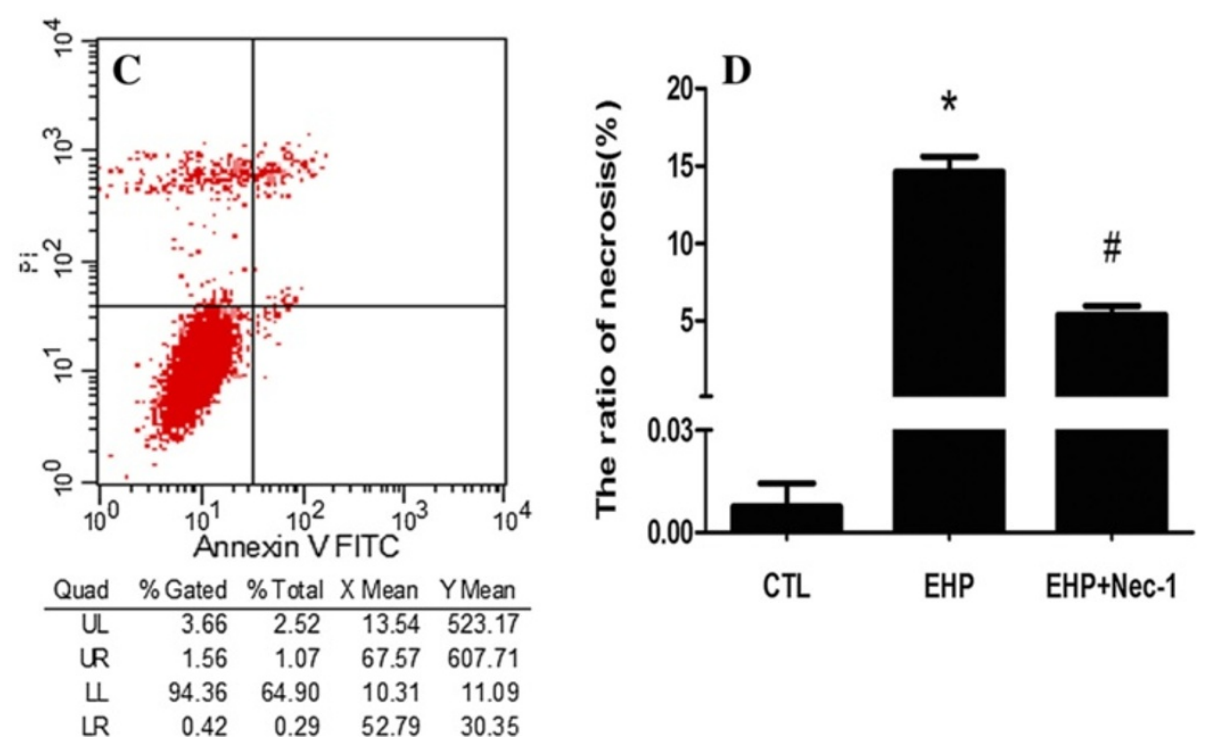

Figure 4 Quantitation of necrotic cells under hydrostatic pressure and Nec-1 usage. Panel A: Normal control cells; Panel B: RGC-5 cell lines necrosis under elevate hydrostatic pressure; Panel C: RGC-5 cell lines were treated with necrostatin-1 (10 $\mu \mathrm{mol} / \mathrm{L})$ to block necroptosis for $24 \mathrm{hr}$ in cell density of $0.6 \times 10^{5} / \mathrm{ml}$ before elevate hydrostatic pressure and analysis of necroptotic cells. Cells were stained with Annexin FITC and PI, and analyzed by FACS using FL1 (Annexin) and FL3 (PI) channels. Panel D: The statistical analysis of RGC-5 necrosis, ${ }^{*}$ vs \# $p<0.05$.

early stage (Figure $5 \mathrm{C}$ ), significantly more distinct calpain bands were shown in $12 \mathrm{hr}$ injury group $(p<0.05)$. It demonstrated that calpain distribution have no difference between injury groups and normal controls, the protein expression levels increased at first and then decreased as time extend within 1 day, which reached the maximum detection in $12 \mathrm{hr}$ group.

\section{AIF cleavage product decreased after calpain inhibition} At first, the bands of tAIF in high pressure groups of $6 \mathrm{hr}, 12 \mathrm{hr}$ and $24 \mathrm{hr}$ increased and then decreased as time extended the maximum detection in $6 \mathrm{hr}$ group (Figure 6A). The statistical analysis of IDV suggested that high pressure up-regulated the cleavage of tAIF in the early stage (Figure 6B), significantly more distinct tAIF band were shown in $12 \mathrm{hr}$ injury group $(p<0.05)$. After ALLN addition, no significant changes of tAIF band in all four groups were detected (Figure 6C), the statistical analysis of IDV also confirmed about these results (Figure 6D), which indicated that there is no difference in protein expression levels in tAIF production in all groups. 


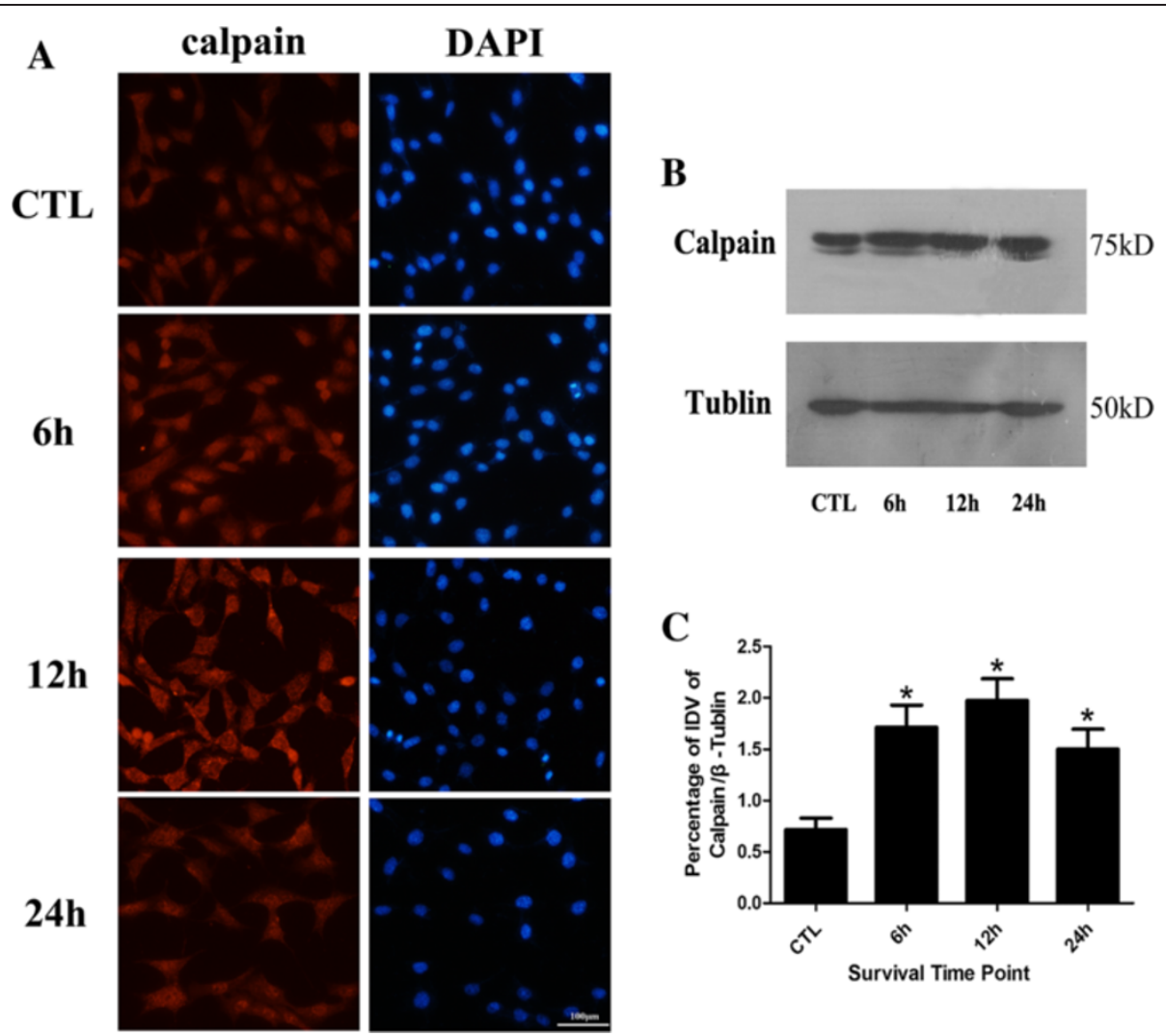

Figure 5 Calpain protein expression level detection. Panel A: Immunofluorescence staining of calpain; Panel B: Western blot of calpain after cell injury; Panel C: The statistical analysis of calpain western blot bands; *: 6 hr, $12 \mathrm{hr}$ and $24 \mathrm{hr}$ group vs CTL group: $p<0.05$, scale bar $=100 \mu \mathrm{m}$ in panel $\mathbf{A}$.
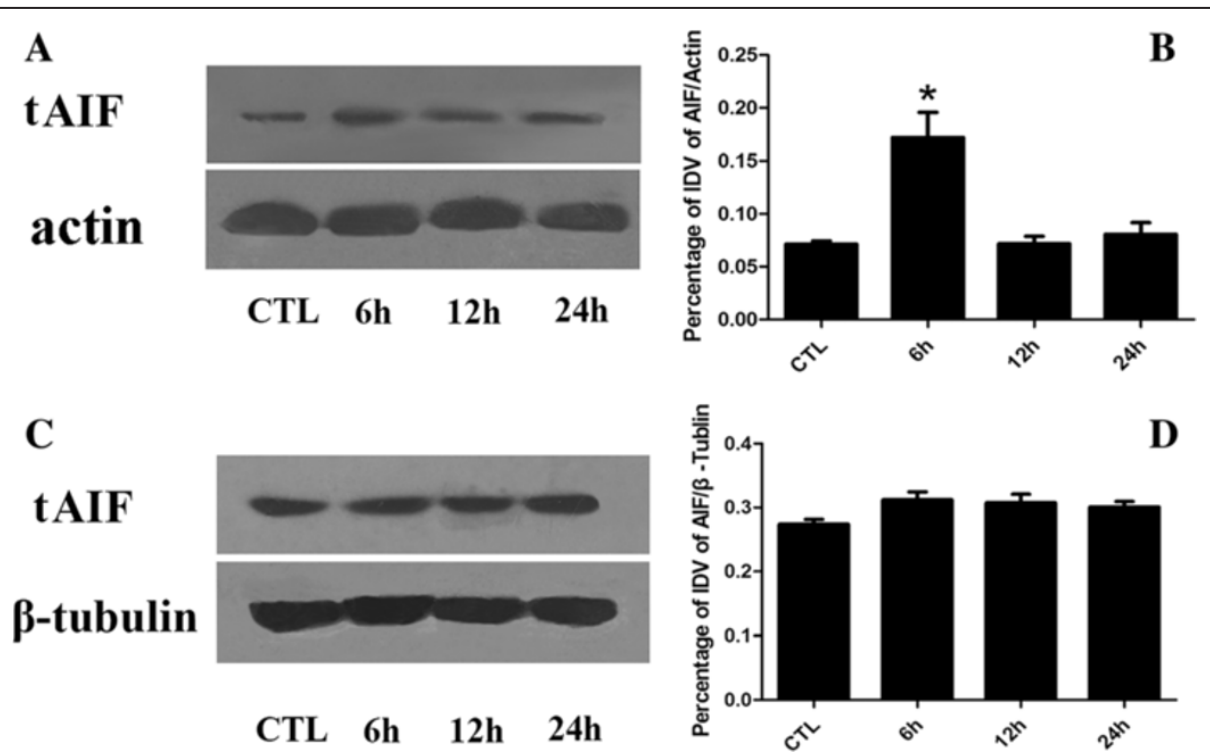

Figure 6 tAIF protein expression level detection. Panel A: Western blot of tAlF after cell injury; Panel B: The statistical analysis of tAIF western blot bands after injury; Panel C: Western blot of tAIF after cell injury pretreated with ALLN; Panel $\mathbf{D}$ : The statistical analysis of tAIF western blot bands after calpain inhibition. *: 6 hr group vs other groups: $p<0.05$. 


\section{Calpain activity assay}

With both the inhibitor and injury groups preteated with ALLN for $24 \mathrm{hr}$, the calpain activity assay appeared to be higher in the inhibitor group (Figure 7). However, at $12 \mathrm{hr}$ there were significant changes between the inhibitor and injury group $(p<0.05)$. It suggested that ALLN may effectively inhibit up-regulation of calpain activity following hydrostatic pressure treatment.

\section{ALLN may decrease the rate of RGC-5 necrosis}

Under $100 \mathrm{mmHg}$ insult, our study showed the occurrence of necroptosis in RGC-5 for $2 \mathrm{hr}$ but recovery at $24 \mathrm{hr}$. Therefore, the cells were treated under this condition with the addition of ALLN. After that, we analyzed cellular necroptosis by using flow cytometry with PI/ Annexin $\mathrm{V}$ double staining to detect whether it could decrease the rate of necrosis in RGC-5 under high pressure condition after calpain activity has been inhibited. The results showed that the ratio of necrosis cells is about $12 \%$ (Figure $8 \mathrm{~B}$ ), the percentage decreased to nearly $8 \%$ upon adding ALLN (Figure $8 \mathrm{C}$ ) in the injury group in $24 \mathrm{hr}$. Similar with Nec-1 treatment, it demonstrated that the ratio of RGC-5 necrosis decreased when treated with ALLN under high pressure condition. Meanwhile, statistical analysis indicated that there were significant changes in PI-positive cells upon adding ALLN compared to normal control group and EHP group (Figure $8 \mathrm{D}$ ), these results indicated that RGC-5 necroptosis in the early stage may be related to the upregulated calpain activity.

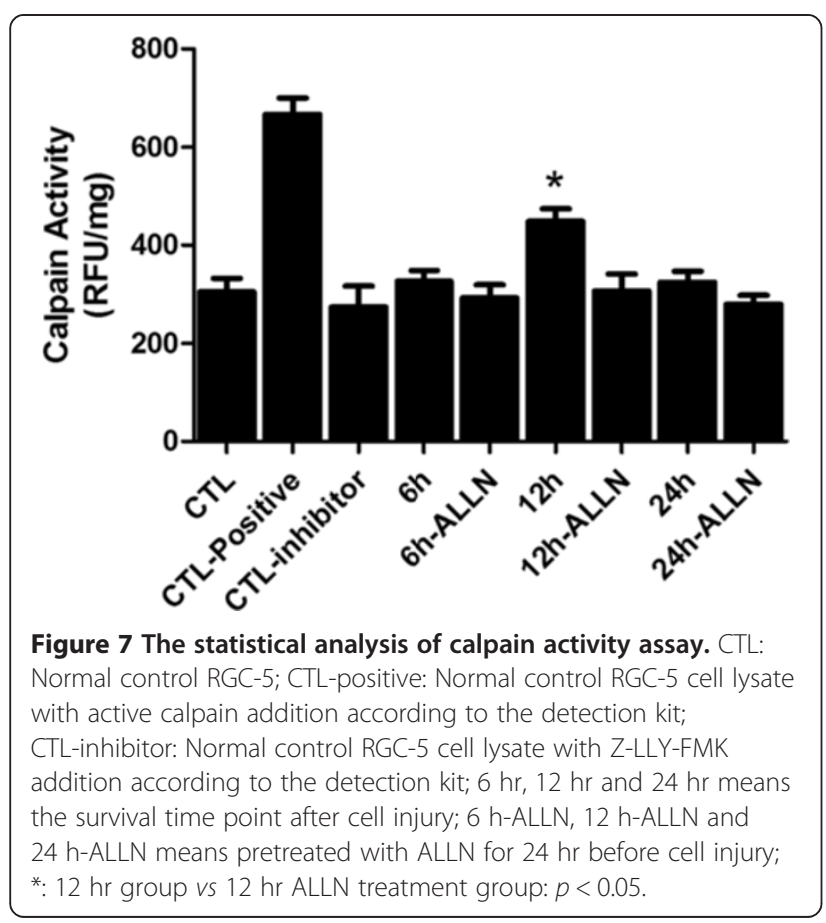

\section{Discussions}

HIOP is one of the main features and risk of visual impairment with ganglion cell death in glaucoma [33-35]. Some research demonstrated that acute increase or continuous arise of intra-ocular pressure (IOP) could lead to visual injury or cell death in retinal ganglion cells, pigment epithelial cells and finally resulting in vision lost. Particularly, retinal ganglion cell death is the most important behavior $[36,37]$ in acute glaucoma. The pathological research model of acute glaucoma is divided into animal model and cell model [16,38,39]. Elevated hydrostatic pressure (EHP) in cultured cell line is commonly used in glaucoma cell model in vitro [40]. In this study, we used open cycling air pressure culture system to gain hydrostatic pressure, the system could set pressure values as required and may easily gain more information via high-throughput experiments [41].

In our study, we chose three pressure values (100 $\mathrm{mmHg}, 30 \mathrm{mmHg}$ and $60 \mathrm{mmHg}$ ) to detect possible levels in necrosis after injury. Among these three pressure values, $100 \mathrm{mmHg}$ represented acute glaucoma (high pressure), $30 \mathrm{mmHg}$ represented low pressure in glaucoma [40] and $60 \mathrm{mmHg}$ was a maximum pressure value in human IOP [42]. The results indicated that the number of PI positive cells increased first and then decreased followed by the time passage in $100 \mathrm{mmHg}$ and 60 $\mathrm{mmHg}$. This is consistent with our previous study on rat (110 $\mathrm{mmHg}$ for $1 \mathrm{hr}$ ) [16], but there was a small number of PI-positive cells in $30 \mathrm{mmHg}$ (data not shown). It was inconsistent with the chronic glaucoma mouse model following 20-30 $\mathrm{mmHg}$ [43], one possibility may be that glaucoma is a neuronal degenerative disease; the symptom might take a longer time to exhibit. Therefore, the fact that having a few obvious necrosis cells in our acute insult for a short time seems to be reasonable. Joo's study have found that necrosis cells existed in ganglion cell layer in 160-180 $\mathrm{mmHg}$ insult for $90 \mathrm{~min}$ following HIOP at $4 \mathrm{hr}$, but a few necrotic cell was observed after $24 \mathrm{hr}$ [44], but we found some necrosis cells existed in $24 \mathrm{hr}$, it might be due to the higher pressure and also cells being kept longer in their study. It may also be related to the complexity in the micro-environment (neighboring cells and the secretion of various factors in interstitial cells). Our experiment demonstrated that cell model after EHP could accurately reflect the injury degree of RGCs. Moreover, Nec-1 has become one of the widely recognized inhibitors in necroptosis [31]. Based on our data, the necroptosis can be found after high pressure insult (100 $\mathrm{mmHg}$ ), and the proportion was reflected by the fact that the necrosis rate decreased to about $5 \%$ after adding Nec-1. Therefore, we speculated one signaling molecules that may induce necroptosis of RGC-5 after EHP.

Previous studies have shown that beside calpain mediated apoptosis, calpain can also induce necroptosis 

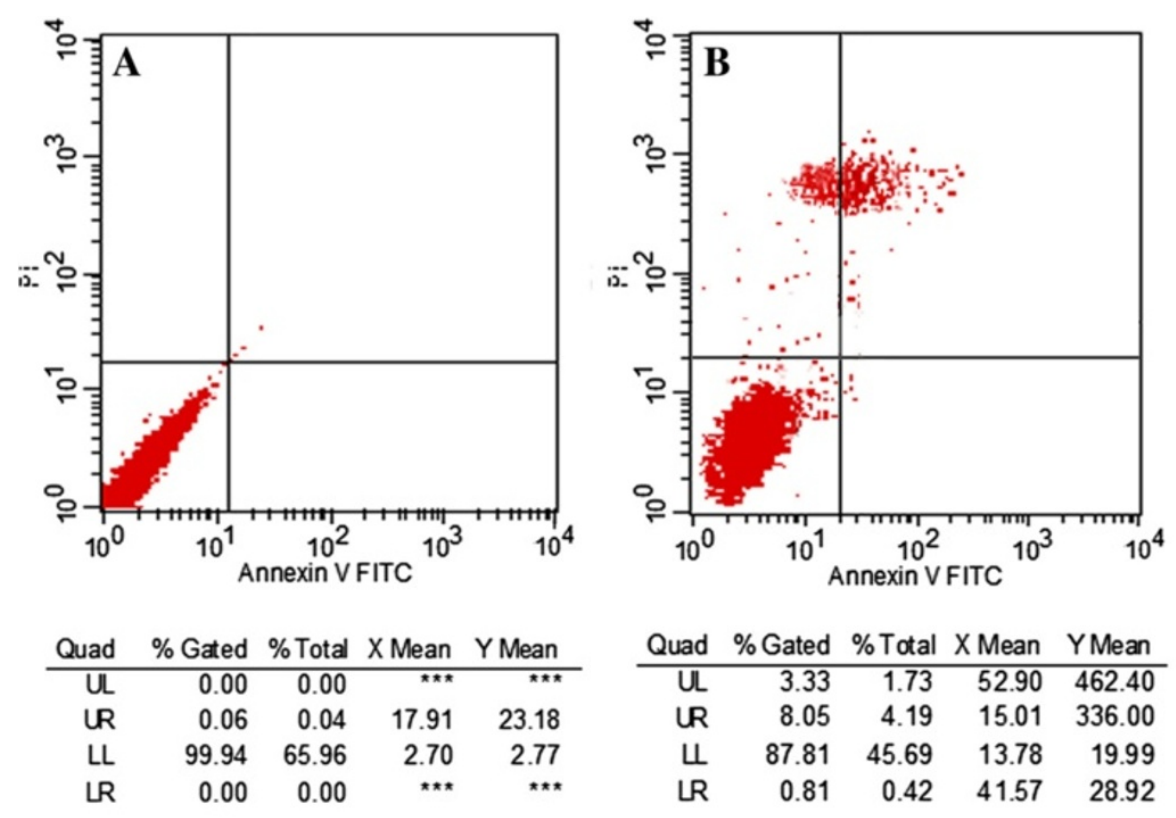

\begin{tabular}{crrrr} 
Quad & \% Gated & \% Total & X Mean & YMean \\
\hline UL & 3.33 & 1.73 & 52.90 & 462.40 \\
UR & 8.05 & 4.19 & 15.01 & 336.00 \\
U & 87.81 & 45.69 & 13.78 & 19.99 \\
LR & 0.81 & 0.42 & 41.57 & 28.92
\end{tabular}
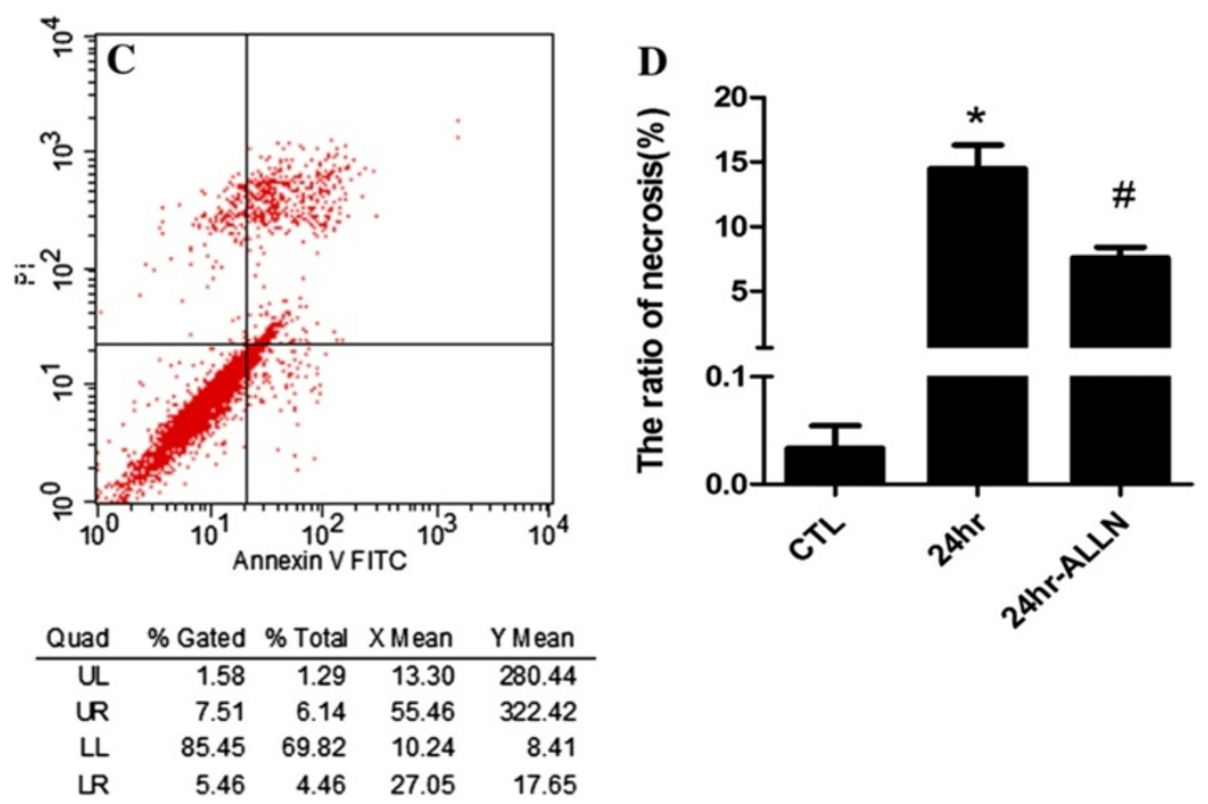

Figure 8 Quantitation of necrotic cells under hydrostatic pressure and calpain inhibition. Panel A: Normal control cells; Panel B: RGC-5 cell lines necrosis under elevate hydrostatic pressure; Panel C: RGC-5 cell lines were pre-treated with ALLN to inhibit calpain activity for 24 hr before elevating hydrostatic pressure; Panel D: The statistical analysis of RGC-5 necrosis. Cells were stained with Annexin FITC and PI, and analyzed by FACS using FL1 (Annexin) and FL3 (PI) channels. *: 24 hr group vs CTL or 24 hr-ALLN treated group: $p<0.05$.

through intracellular signal pathway. Calpain facilitates BAX activation and activated BAX favors the release of tAIF from mitochondria to the cytosol which could induce necroptosis $[10,11]$. Calpain may be one of the important regulatory molecules participating in necroptosis in the cells like fibroblast, nephrocyte, HeLa cell and vascular endothelial cells, etc. Some early necroptosis may be mediated by calpain [9-11,45]; however, the biological function of calpain-mediating early neuronal necroptosis in nervous system especially the visual nervous system is largely unveiled. Our western blot results showed that calpain protein levels appeared to decrease after an initial increase, and reached maximum at $12 \mathrm{hr}$ following elevated hydrostatic pressure condition in RGC-5. In this study, the immunofluorescence staining results showed that calpain was mainly present in the cytoplasm of RGC-5. Moreover, in contrast with other groups, significantly more distinct and heavier calpain 
immunoreactive were shown in $12 \mathrm{hr}$ group. Both of these results showed that the expression of calpain was significantly up-regulated in RGC-5 following elevated hydrostatic pressure condition accompanied with the phenotype of the increased ratio of necroptosis. This observation in regards to the expression profile of calpain consists of what we found in gene chip detection in RGC-5 following elevated hydrostatic pressure in our previous experiment (our previous unpublished data). In contrast, necroptosis was reduced to a certain extent when exposed to ALLN, a specific calpain inhibitor targeting the activity rather than the expression [46], measured by flow cytometry. Collecting all these results together, it suggested that calpain may play an important role in early RGC-5 necroptosis following elevated hydrostatic pressure condition.

In our experiment, with ALLN intervention the expression of calpain remained high while the activity was markedly inhibited in RGC-5 following elevated hydrostatic pressure condition. Moreover, tAIF (the cleaved form of AIF) didn't significantly increase, which resulted in less effect on RGC-5. Meanwhile, the number of necroptosis cells didn't significantly increase either. It further demonstrated that calpain in RGC-5 was mediated by the downstream molecule of tAIF to modulate necroptosis pathway. Overall, the necroptosis regulated by calpain mediated by tAIF may be a mode of RGCs death induced by elevated hydrostatic pressure. Regarding to another risk factor, cellular hypoxic exposure is not only the widely used nervous system injury model [47], but also one of the important pathophysiological mechanisms of aHIOP [48]. Therefore, it is worthwhile to further investigate whether necroptosis is mediated by calpain in hypoxic exposure. It will be helpful for comprehensive understanding about RGC-5 necroptosis in aHIOP. Taken all together, the result provided novel evidence for the molecular mechanism (non-RIP3 pathway) research of the early RGCs in aHIOP and new interventional target for reducing early RGCs necroptosis in aHIOP patients.

\section{Conclusion}

Our study found that calpain may induce necroptosis via tAIF-modulation in RGC-5 following elevated hydrostatic pressure.

\section{Competing interests}

The authors declare that they have no competing interests.

\section{Authors' contributions}

LS, KX and JFH designed the experiment, LS and KX performed the experiment, WD and SC analyzed the data, LS, RFM and KX drafted the manuscript, LXX participated in paper modification and revised the manuscript for English writing, all authors participated in critical revision of the manuscript and approved the final manuscript.

\section{Acknowledgements}

This study was supported by National Natural Science Foundation of China (No. 81371011, 81070729); Natural Science Foundation of Hunan Province (No. 11JJ2020); Young Teachers Training Program of University of Hunan Province. We would like to thank PhD. Anna Chun-Ling, Neuroprotection Research Laboratory, Massachusetts General Hospital, Boston, USA, who edited the manuscript for us.

\section{Author details}

'Department of Anatomy and Neurobiology, Central South University School of Basic Medical Sciences, 172 Tongzi Po Road, 410013 Changsha, Hunan, China. ${ }^{2}$ Department of Biochemistry and Molecular Biology, Peking University Health Science Center, 100191 Beijing, China. ${ }^{3}$ Xiangya School of Medicine, Central South University, 410013 Changsha, Hunan, China.

Received: 12 March 2014 Accepted: 28 April 2014

Published: 12 May 2014

\section{References}

1. Sobhan PK, Seervi M, Deb L, Varghese S, Soman A, Joseph J, Mathew KA, Raghu G, Thomas G, E S, S M, R SK: Calpain and reactive oxygen species targets Bax for mitochondrial permeabilisation and caspase activation in zerumbone induced apoptosis. PLoS One 2013, 8(4):e59350.

2. Xiao T, Zhang Y, Wang Y, Xu Y, Yu Z, Shen X: Activation of an apoptotic signal transduction pathway involved in the upregulation of calpain and apoptosis-inducing factor in aldosterone-induced primary cultured cardiomyocytes. Food Chem Toxicol 2013, 53:364-370.

3. Zhao H, Chang R, Che H, Wang J, Yang L, Fang W, Xia Y, Li N, Ma Q, Wang $X$ : Hyperphosphorylation of tau protein by calpain regulation in retina of Alzheimer's disease transgenic mouse. Neurosci Lett 2013, 551:12-16.

4. Esteves AR, Arduino DM, Swerdlow RH, Oliveira CR, Cardoso SM: Dysfunctional mitochondria uphold calpain activation: contribution to Parkinson's disease pathology. Neurobiol Dis 2010, 37(3):723-730.

5. Morton JD, Lee HY, McDermott JD, Robertson $L$, Bickerstaffe R, Jones MA, Coxon JM, Abell AD: A macrocyclic calpain inhibitor slows the development of inherited cortical cataracts in a sheep model. Invest Ophthalmol Vis Sci 2013, 54(1):389-395.

6. Blomgren K, Zhu C, Wang X, Karlsson JO, Leverin AL, Bahr BA, Mallard C, Hagberg H: Synergistic activation of caspase-3 by m-calpain after neonatal hypoxia-ischemia: a mechanism of "pathological apoptosis"? J Biol Chem 2001, 276(13):10191-10198.

7. Huang W, Li G, Qiu J, Gonzalez P, Challa P: Protective effects of resveratrol in experimental retinal detachment. PLoS One 2013, 8(9):e75735.

8. Martinez-Fernandez de la Camara C, Sequedo MD, Gomez-Pinedo U, Jaijo T, Aller E, Garcia-Tarraga P, Garcia-Verdugo JM, Millan JM, Rodrigo R: Phosphodiesterase inhibition induces retinal degeneration, oxidative stress and inflammation in cone-enriched cultures of porcine retina. Exp Eye Res 2013, 111:122-133.

9. Autheman D, Wyder M, Popoff M, D'Herde K, Christen S, Posthaus H: Clostridium perfringens beta-toxin induces necrostatin-inhibitable, calpain-dependent necrosis in primary porcine endothelial cells. PLoS One 2013, 8(5):e64644

10. Cabon L, Galan-Malo P, Bouharrour A, Delavallee L, Brunelle-Navas MN, Lorenzo HK, Gross A, Susin SA: BID regulates AIF-mediated caspaseindependent necroptosis by promoting BAX activation. Cell Death Differ 2012, 19(2):245-256.

11. Sosna J, Voigt S, Mathieu S, Lange A, Thon L, Davarnia P, Herdegen T, Linkermann A, Rittger A, Chan FK, Kabelitz D, Schütze S, Adam D: TNF-induced necroptosis and PARP-1-mediated necrosis represent distinct routes to programmed necrotic cell death. Cell Mol Life Sci 2013, 71(2):331-348.

12. Miglior S, Bertuzzi F: Relationship between intraocular pressure and glaucoma onset and progression. Curr Opin Pharmacol 2013, 13(1):32-35.

13. Le PV, Tan O, Chopra V, Francis BA, Ragab O, Varma R, Huang D: Regional correlation among ganglion cell complex, nerve fiber layer, and visual field loss in glaucoma. Invest Ophthalmol Vis Sci 2013, 54(6):4287-4295.

14. Banitt MR, Ventura LM, Feuer WJ, Savatovsky E, Luna G, Shif O, Bosse B, Porciatti V: Progressive loss of retinal ganglion cell function precedes structural loss by several years in glaucoma suspects. Invest Ophthalmol Vis Sci 2013, 54(3):2346-2352. 
15. Rosenbaum DM, Degterev A, David J, Rosenbaum PS, Roth S, Grotta JC, Cuny GD, Yuan J, Savitz SI: Necroptosis, a novel form of caspaseindependent cell death, contributes to neuronal damage in a retinal ischemia-reperfusion injury model. J Neurosci Res 2010, 88(7):1569-1576.

16. Huang JF, Shang L, Zhang MQ, Wang H, Chen D, Tong JB, Huang H, Yan $X X$, Zeng LP, Xiong K: Differential neuronal expression of receptor interacting protein 3 in rat retina: involvement in ischemic stress response. BMC Neurosci 2013, 14:16.

17. Fulda S: The mechanism of necroptosis in normal and cancer cells. Cancer Biol Ther 2013, 14(11):999-1004.

18. Murphy JM, Czabotar PE, Hildebrand JM, Lucet IS, Zhang JG, Alvarez-Diaz S, Lewis R, Lalaoui N, Metcalf D, Webb Al, Young SN, Varghese LN, Tannahill GM, Hatchell EC, Majewski IJ, Okamoto T, Dobson RC, Hilton DJ, Babon JJ, Nicola NA, Strasser A, Silke J, Alexander WS: The Pseudokinase MLKL Mediates Necroptosis via a Molecular Switch Mechanism. Immunity 2013, 39(3):443-453.

19. Wang $X X$, Liu $X Q$, Zhao L: [Research progress on necroptosis regulation mechanism and its clinical relevance]. Zhongguo Shi Yan Xue Ye Xue Za Zhi 2012, 20(4):1025-1029.

20. Dan C, Jian-Bin T, Hui W, Le-Ping Z, Jin Z, Ju-Fang H, Xue-Gang L: Synaptophysin expression in rat retina following acute high intraocular pressure. Acta histochemica et cytochemica 2008, 41(6):173-178.

21. Danesh-Meyer HV: Neuroprotection in glaucoma: recent and future directions. Curr Opin Ophthalmol 2011, 22(2):78-86.

22. Li GY, Li T, Fan B, Zheng YC, Ma TH: The D(1) dopamine receptor agonist, SKF83959, attenuates hydrogen peroxide-induced injury in RGC-5 cells involving the extracellular signal-regulated kinase/p38 pathways. Mol Vis 2012, 18:2882-2895.

23. Ju WK, Kim KY, Lindsey JD, Angert M, Patel A, Scott RT, Liu Q, Crowston JG, Ellisman $\mathrm{MH}$, Perkins GA, Weinreb RN: Elevated hydrostatic pressure triggers release of OPA 1 and cytochrome $C$, and induces apoptotic cell death in differentiated RGC-5 cells. Mo/ Vis 2009, 15:120-134.

24. Cordeiro MF, Guo L, Coxon KM, Duggan J, Nizari S, Normando EM, Sensi SL, Sillito AM, Fitzke FW, Salt TE, Moss SE: Imaging multiple phases of neurodegeneration: a novel approach to assessing cell death in vivo. Cell Death \& Disease 2010, 1:e3.

25. Shahabuddin MS, Nambiar M, Moorthy BT, Naik PL, Choudhary B, Advirao GM, Raghavan SC: A novel structural derivative of natural alkaloid ellipticine, MDPSQ, induces necrosis in leukemic cells. Invest New Drugs 2011, 29(4):523-533.

26. Krysko DV, Vanden Berghe T, D'Herde K, Vandenabeele P: Apoptosis and necrosis: detection, discrimination and phagocytosis. Methods 2008 44(3):205-221.

27. Fu Z, Deng B, Liao Y, Shan L, Yin F, Wang Z, Zeng H, Zuo D, Hua Y, Cai Z: The anti-tumor effect of shikonin on osteosarcoma by inducing RIP1 and RIP3 dependent necroptosis. BMC Cancer 2013, 13:580.

28. Ma L, Song B, Jin H, Pi J, Liu L, Jiang J, Cai J: Cinobufacini induced MDAMB-231 cell apoptosis-associated cell cycle arrest and cytoskeleton function. Bioorg Med Chem Lett 2012, 22(3):1459-1463.

29. Huang J, Zhou L, Wang H, Luo J, Zeng L, Xiong K, Chen D: Distribution of thrombospondins and their neuronal receptor alpha2delta1 in the rat retina. Exp Eye Res 2013, 111:36-49.

30. Chen WW, Yu H, Fan HB, Zhang CC, Zhang M, Zhang C, Cheng Y, Kong J, Liu CF, Geng D, Xu X: RIP1 mediates the protection of geldanamycin on neuronal injury induced by oxygen-glucose deprivation combined with zVAD in primary cortical neurons. J Neurochem 2012, 120(1):70-77.

31. Wang $Y$, Wang $H$, Tao $Y$, Zhang $S$, Wang J, Feng $X$ : Necroptosis inhibitor necrostatin-1 promotes cell protection and physiological function in traumatic spinal cord injury. Neuroscience 2014, 266:91-101.

32. Han W, Xie J, Li L, Liu Z, Hu X: Necrostatin-1 reverts shikonin-induced necroptosis to apoptosis. Apoptosis 2009, 14(5):674-686.

33. Bowman RJ, Hay A, Wood ML, Murdoch IE: Combined cataract and trabeculectomy surgery for advanced glaucoma in East Africa; visual and intra-ocular pressure outcomes. Eye (Lond) 2010, 24(4):573-577.

34. Huang C, Cen LP, Liu L, Leaver SG, Harvey AR, Cui Q, Pang CP, Zhang M: Adeno-associated virus-mediated expression of growth-associated protein-43 aggravates retinal ganglion cell death in experimental chronic glaucomatous injury. Mol Vis 2013, 19:1422-1432.

35. Scott EM, Boursiquot N, Beltran WA, Dubielzig RR: Early histopathologic changes in the retina and optic nerve in canine primary angle-closure glaucoma. Vet Ophthalmol 2013, 16(Suppl 1):79-86.
36. Medeiros FA, Weinreb RN: Medical backgrounders: glaucoma. Drugs Today (Barc) 2002, 38(8):563-570.

37. Ofri R: Intraocular pressure and glaucoma. Vet Clin North Am Exot Anim Pract 2002, 5(2):391-406. vii-viii.

38. Pang $H_{\text {, }}$ McCartney MD, Steely HT, Clark AF: Human ocular perfusion organ culture: a versatile ex vivo model for glaucoma research. J Glaucoma 2000, 9(6):468-479.

39. Tong JB, Chen D, Zeng LP, Mo XY, Wang H, Huang J, Luo XG: Differential changes of local blood supply in rat retinae are involved in the selective loss of retinal ganglion cells following the acute high intraocular pressure. Curr Eye Res 2010, 35(5):425-434

40. Agar A, Li S, Agarwal N, Coroneo MT, Hill MA: Retinal ganglion cell line apoptosis induced by hydrostatic pressure. Brain Res 2006, 1086(1):191-200.

41. Zhang H, Li GG, Wang XF, Hu WK, Xie EJ, Chen LY, Shan CM, Zhao GH: [Development of open cycling air pressure control system used for glaucoma research]. Zhonghua Yan Ke Za Zhi 2006, 42(6):513-516.

42. Tan SZ, Sampat K, Rasool S, Nolan d: Unilateral acute angle closure glaucoma. BMJ Case Reports 2013, 32(9):e113-5.

43. Kalesnykas G, Oglesby EN, Zack DJ, Cone FE, Steinhart MR, Tian J, Pease ME, Quigley HA: Retinal ganglion cell morphology after optic nerve crush and experimental glaucoma. Invest Ophthalmol Vis Sci 2012, 53(7):3847-3857.

44. Joo CK, Choi JS, Ko HW, Park KY, Sohn S, Chun MH, Oh YJ, Gwag BJ: Necrosis and apoptosis after retinal ischemia: involvement of NMDA-mediated excitotoxicity and p53. Invest Ophthalmol Vis Sci 1999 40(3):713-720.

45. Linkermann A, De Zen F, Weinberg J, Kunzendorf U, Krautwald S: Programmed necrosis in acute kidney injury. Nephrol Dial Transplant 2012, 27(9):3412-3419.

46. Mckernan DP, Guerin MB, O'Brien CJ, Cotter TG: A key role for calpains in retinal ganglion cell death. Invest Ophthalmol Vis Sci 2007, 48(12):5420-5430.

47. Yao L, Kan EM, Kaur C, Dheen ST, Hao A, Lu J, Ling EA: Notch-1 Signaling Regulates Microglia Activation via NF-kappaB Pathway after Hypoxic Exposure In Vivo and In Vitro. PLoS One 2013, 8(11):e78439.

48. Ju WK, Liu Q, Kim KY, Crowston JG, Lindsey JD, Agarwal N, Ellisman MH, Perkins GA, Weinreb RN: Elevated hydrostatic pressure triggers mitochondrial fission and decreases cellular ATP in differentiated RGC-5 cells. Invest Ophthalmo/ Vis Sci 2007, 48(5):2145-2151.

doi:10.1186/1471-2202-15-63

Cite this article as: Shang et al:: Calpain: a molecule to induce

AIF-mediated necroptosis in RGC-5 following elevated hydrostatic pressure. BMC Neuroscience 2014 15:63.

\section{Submit your next manuscript to BioMed Central and take full advantage of:}

- Convenient online submission

- Thorough peer review

- No space constraints or color figure charges

- Immediate publication on acceptance

- Inclusion in PubMed, CAS, Scopus and Google Scholar

- Research which is freely available for redistribution 